\title{
Research Review on the Transition of Communist Party of China
}

\author{
Zehua Chen \\ School of Marxism \\ Wuhan University of Science and Technology \\ Wuhan, China
}

\author{
Haifen $\mathrm{Fu}$ \\ School of Marxism \\ Wuhan University of Science and Technology \\ Wuhan, China
}

\begin{abstract}
The transition issues of political parties are the important contents of research on the typology of political parties. Political parties have been reformed ceaselessly since its emergence. The modern transition of political parties and party politics has become a worldwide phenomenon. With the rising of research on party transition, the transition of Communist Party of China gradually enters the research perspective of scholars at home and abroad. Systematically understanding the current situation regarding the transition research on the Communist Party of China and grasping the research results of the educational circles on the concept definition, basic contents, path choice and dilemma analysis of the transition of Communist Party of China is the premise to further deepen the research and has the crucial academic value and practical significance.
\end{abstract}

Keywords-Communist Party of China; party transition; review

\section{INTRODUCTION}

From the perspective of the development history of the world's political parties, the transition of political parties is universal. Political parties around the world are in the process of ceaseless reform, innovation, development and transition. Communist Party of China has been conducting continuous self-adjustment, self-renewal, self-improvement and selftranscendence since its birth in 1921 to unceasingly adapt to the objective realistic environment that has changed. Researches of scholars at home and abroad on the transition of political parties and the transition of Chinese political party have achieved corresponding outcomes from different perspectives. It is not only precious literature resources and has important values for scholars to conduct in-depth exploration in the future.

\section{BASIC CONCEPTS OF TRANSITION AND THE TRANSITION OF POLITICAL PARTIES}

The word "transition" first appeared in the mid-14th century of Britain. According to the explanation of English Etymology Dictionary, the word at that time means changing shapes or forms. According to the explanation of Cambridge Dictionary, "transition" mainly has meaning of two levels: first means the revolution of things or people regarding progress; second means the process of genetic inheritance, variation and evolution of biology. With the changes of time and social development, scholars of all fields describe the innovation and transformation of research objects by virtue of the concept of "transition", such as social transition, economic transition, political transition, cultural transition and management transition.

The transition issues of political party as the center of modern political structure have attracted increasing attentions of scholars. The transition of political party "means reforms in form, appearance, structure, nature, trend, characteristics and background", means the process that a political party conducts adaptive adjustment, reform and innovation of its idea (ideology), structure (relationship between party and nation, society) and function (role of the party in society) with the changes of social status, tasks and social ecological environment. It is the "creative transformation" of political party, and the transformation "must promote and lead to a result of higher quality"1 and it means "political party conducts self-reform consciously or under compulsion to respond to crisis". ${ }^{2}$

\section{RESEARCH STATUS OF THE FOREIGN ACADEMIC} CIRCLE ON THE TRANSITION OF COMMUNIST PARTY OF CHINA

In the book of Iron Law of Oligarchy --- Political Sociology in Modern Democratic System, western scholar Michels had systematically analyzed the political parties in Germany, France and Italy in 1911. It is the first literature that researches on the transition of political parties. He states the internal problems in party organization and the interaction between different party organizations and issues related to political parties and governments and raised the renowned judgment of Iron Law of Oligarchy from the perspective of life cycle. [1] Works of Weber and Huntington include relatively systematic researches on the basis of legitimacy, but these researches lay particular stress on the common analysis about the issues of legitimate foundation faced by western countries or third world countries, seldom involving the legitimate foundation of political party in contemporary China, or the statement is biased because of cultural background. [2] Western scholars have also paid attention to the culture of Communist Party of China. The History of the People's

Liu Changjiang. Transition and Cartelization of Political Parties [J], the Journal of Jiangsu Administration Institute, 2010

[Germany]Werner Pfennig. Transition of Political Parties: Reform of German Social Democratic Party [J], translated by Liu Peng. Comparative Economic and Social Systems, 2006 
Republish of China in Cambridge with editors-in-chief of $\mathrm{R}$ Macfarquhar and John King Fairbank has involved the cultural construction and development of Communist Party of China in many aspects. [3]

Thomas Heberer holds the opinion that the "political party --- state system" of China has experienced the periods of "transition" and "consolidation" and has entered the third period of "adjustment" at present. In this period, the one-party leadership system of China has five characteristics: Firstly, the effect of ideology is weakened. Secondly, the emergence of new and rising forces in society requires the party to redefine the role of party in the society. Thirdly, the new political elites appear. Fourthly, critical intellectual stratum reappears. Fifthly, regional and trans-regional social groups and organizations increasingly request to participate in and influence the political process. According to these characteristics, we can judge the "political party-state system" in China is not an entity of homogeny but a diversified entity. [4] (P6-P7). American scholar David Shambaugh thinks the evolution of China's "political party - state" system is a dual process of "shrinkage" and "adjustment" after the drastic change in Soviet Union and East Europe even earlier time. The shrinkage of "political party-state system" embodies in politics, economy, thought and social life: The traditional control measures greatly shrink and are eroded with the elapse of time, and the globalization and the interaction between China and outside world have weakened the party's control of society. In addition, the party is also facing many pressing challenges, such as the increasingly intensive social stratification and inequality, extensive corruption, general unemployment, rise of crime rate and instability of rural areas. [4] (7)

Womack observes the leaders of Communist Party of China in the past years have developing a political guiding thought. Developing into a modern and prosperous country is the present urgent hope and need of China also the realization of national interest. Whether Communist Party of China can meet the need and interest will become the basis for Communist Party of China to maintain and prove the ruling status. Under the framework of the rule of law of national government, the party roundly and effectively promotes the interest of people and guarantees the appropriate autonomy of individuals and organizations. On this basis, the "three representative thought" has promised stability, tried to integrate the ruling status of the party with people's interest to maintain the existing political system. Therefore, the objective is to realize the national democracy of political party. [4] (P96)

To sum up, the researches of scholars at abroad at abroad on the transition of Communist Party of China base on China's specific political system, political party system and national condition, deeply explore the reform and innovation made by Communist Party of China to respond to international and domestic patterns since the reform and opening up and have important reference values.

\section{CURRENT SituATION OF RESEARCHES ON THE TRANSITION OF COMMUNIST PARTY OF CHINA IN DOMESTIC ACADEMIC WORLD}

According to the data collected, articles of domestic academic world regarding the transition of Communist Party of China appeared in 2002. From then on, domestic academic world pays more and more attentions to the research on the transition issue of Communist Party of China and has made fruitful achievements.

\section{A. Viewing the Changes of the Social Status and Role of Communist Party of China, the Transition Is from \\ Revolutionary Political Party to Ruling Party}

At present, domestic academic world has not reached a conclusion on the concept of transition of Communist Party of China, but most researches exist regarding the changes of social status and role of Communist Party of China, namely the transition from revolutionary political party to ruling party.

Wang Guixiu thinks the change of Communist Party of China from revolutionary political party to ruling party is an extremely complicated issue. Observing from different points of view, huge differences exist between the change of proletarian party from revolutionary political party to ruling party and the change of bourgeois political party from revolutionary political party to ruling party; our party has experienced the development process from "local ruling" to "national ruling"; the party has realized "change of status" since the founding of the People's Republic of China in 1949, but fails to realize "change of role" in a long period of time, forming the historical dislocation and conflict of "revolutionary (party) role" and "ruling (party) status". It mainly shows in the conflicts between revolutionary idea and ruling status, between revolutionary system and ruling status. We should devote to eradicating the conflict in today when we emphasize strengthening the construction of ruling party. [5]

Liu Nan thinks, "Different from the modern transition of political parties in western countries and their party politics, Communist Party of China mainly centralizes on the issue of transition from revolutionary political party to ruling party. The core of Chinese politics is the issue of the party." In the process of transition and construction, our party has conducted effective exploration. Comrade Deng Xiaoping puts forward the economic construction should be the priority of work of the party and advocates construction of party system; comrade Jiang Zemin raises the important thought of "three representative", expanding the legitimate foundation of ruling in our party; comrade $\mathrm{Hu}$ Jintao raises the comprehensive construction of the party's ruling ability. [6]

Wang Lihua and Sun Qiongxian address the Communist Party of China is produced in the semi-colonial and semifeudal society. Facing the nation and society without democratic system at home and without national independence at abroad, the party selected the path of seizing power via violence and became the revolutionary political party. In the sixty years of ruling, the Communist Party of China has not only realized the change from the status of revolutionary political party to the status of ruling party, but also realized the change from the role of revolutionary political party to the role 
of ruling party in the aspects of idea, structure and function. That is to say, the ideology of the party ceaselessly keeps abreast of the times and the party blazes new trails in a pioneering spirit, gradually changing from holiness to secularity, from belligerence to containment and from closure to openness; the power structure of party, nation and society gradually changes from the highly-centralized leading system to the leadership style of ruling scientifically, democratically and by law; the function on society gradually changes from the power of conflict to the integrated tool. [7]

Jiang Yiwei and Chen Yang observe the Communist Party of China realized the first transition from the revolutionary political party to ruling party in the founding of the People's Republic of China in 1949, and overcame the state that social organizations were low and state power was disperse, having provided a solid authoritative basis for Chinese modernization." "After the reform and opening up, the Communist Party of China realized the second transition from ruling party to governing party and had answered the legitimacy issues in the national construction and clarified the relationship between "rule of law" and "adherence to the party's leadership", providing theoretical support to promote the four comprehensive strategic layout in the new period." [8]

\section{B. Basic Contents in the Transition of Communist Party of China}

1) Transition of the governing idea of Communist Party of China: Governing idea is the party's ruling principle and guiding thought established on understanding the governing law. The fundamental principle of the party's governing activities is the rational understanding of ruling for whom, depending on whom and how to rule.

Xie Junyu observes the transition of Communist Party of China has different characteristic expression from the 8th National Congress of Communist Party of China to the 17th National Congress of Communist Party of China in aspects of ruling target, mass base and guiding thought, from the perspective of the change of governing idea. In terms of the ruling target, the report in the 8th National Congress of Communist Party of China explicitly raised the nation's restriction on the capitalist industry and commerce; the 13th National Congress of Communist Party of China established the basic line of our party in the primary stage of socialism; after the 17th National Congress of Communist Party of China, the party brings the ideas of scientific development and harmonious society in the work. Secondly, on the mass base, the Communist Party of China shows the inclusive state, and the involvement of multiple classes has expanded the mass base of the party. Finally, in regard to the guiding thought, the party's ideological and theoretical construction has been the fundamental of party construction, having reflecting the governing idea of the party to a large extent. [9]

Tang Aijun thinks the Communist Party of China ceaselessly promote the discourse transition of the mainstream ideology according to the changes of era condition and historical task. Since the reform and opening up, the party has realized the historical transition of ideology from "revolution" discourse to "construction" discourse and improved the power of explanation and attraction. Besides, discourse change also exists inside the ideology with "construction" as the core discourse, constantly realizing the changes from the discourse based on "development efficiency" to the value discourse based on realizing "beautiful life". [10]

2) Transition of the ruling style and ruling legitimacy of Communist Party of China: The reform of the ruling style of Communist Party of China is the application and expression of theories in reality. To achieve and consolidate the leader status, a political party should get the support of most of the people and the approval of social members through concrete procedures, namely, the legitimacy construction on procedural meaning must be strengthened.

Huang Ruibo and Lyu Yuanli address the ruling style of Communist Party of China is the transition from closure to openness. First of all, the guiding thought of the party moves from "closed and rigid" to "opening innovation". In the second place, the general plan and step of the party is "compatible and gradually", replacing "intolerance and radicalization". Finally, the form of the party's force is: moving from "one-sidedly emphasizing class nature" to "paying special attention to extensiveness". [11] Li Guimin thinks the ruling style of Communist Party of China has experienced the changes from mainly depending on policies to depending on both policies and laws and to mainly depending on laws. The transition of ruling basis requests Communist Party of China to establish the consciousness of ruling by law, improve legislation and strengthen the legal education of cadres. At the meantime, the party must establish and improve the power supervision mechanism, handle with the relationship between good policies and laws and maintain the legitimacy of policies. [12]

Tao Lin observes the ruling legitimacy of Communist Party of China has experienced two stages of ideological dominance (1949 to 1978) and dominance of economic performance (1978 to 2002). The global development has brought the ruling legitimacy of Communist Party of China the comprehensive challenges of economy, politics and culture, compelling the transition of the ruling legitimacy of Communist Party of China: insist on scientific development view economically; promote reform of political structure politically; adhere to the guiding role of Marxism culturally, leading social thoughts via socialist core value system. [13] Zhao Haitao says whether the ruling party in the period of social transition can successfully build the legitimacy, whether can avoid the pain brought by the legitimate crisis and whether can consolidate the ruling status in the long run mainly depends on whether the party can grasp the evolvement rule of the basis of ruling legitimacy to adapt to the rapidly changing situations and realize the dynamic equilibrium development of politics through developing various technical legitimacy basis. [14]

3) Transition of cultural construction of Communist Party of China: Culture is the important source of national cohesion and creativity, the important factor of comprehensive national power competition and the crucial support of economic and social development. Communist Party of China has taken Marxism as the guidance and shouldered the responsibility of 
reforming Chinese society since its founding. Cultural issues have been considered by Communists very early.

Liang Jiaming thinks the cultural construction of Communist Party of China is a dynamic process. Each social transition has inevitably brought effects on the cultural construction of Communist Party of China since the birth of it. In the period of reform and opening up, the transition of cultural construction of Communist Party of China is mainly: developing from "class struggle" to "harmonious society", from destroying the old world to constructing a new world, from depending on the rule of man to the organic unity of "three styles of ruling", from excessive concentration of power to diligently practicing democratic centralism, from emphasizing class interests to coordinating and integrating the interests of all aspects. [15]

Yang Fengcheng observes the basic viewpoints regarding cultural issues and formed by the early Chinese Communists according to the principle of Marxism have continued so far. The core problem in the cultural views of Communist Party of China restricting the policies of cultural construction is the relationship between culture and politics. In this regard, its cultural views have experienced the changes from proletarian politics service to constructing socialist culture with Chinese characteristics. At the same time, contemporary Chinese culture experiences two transitions from pluralism to unity, from unity to the coexistence of multiplicity under the dominance of unity. [16]

4) Transition of way of thinking of Communist Party of China: Certain theoretical thinking is the practical product of certain historic period and is evolving and developing with the time-to-space conversion of historic period and the changes of practice basis.

Chen Chunsheng thinks certain theoretical thinking is the practical product of certain historic period. The theoretical thinking mode of Communist Party of China changes from the contending thinking under the background of "war and revolution" to the harmonious thinking that adapts to "construction and development" in the aspects of economy, politics and ideology and happens on the basis of conversion of historical background from revolution to construction and practical requirements. The change of the theoretical thinking mode has its objective necessity. [17]

Zhang Bo addresses the theoretical foundation for the transition of ruling thought of Communist Party of China is that the thinking of rule of law is superior to the thinking of rule of man. The traditional thinking of rule of man is the realistic reason for the transition of ruling thought of Communist Party of China because it still rejects and dispels the thinking of rule of law because of the inertia effect of mindset. In regard to the proposition that improves the legal thinking ability of leading cadres, the 18th National Congress of the Communist Party of China has proposed the critical group in the transition of ruling thought of the party. The thinking of rule of man breeds ways of rule of man, and the thinking of rule of law corresponds to ways of rule of law, realizing the modern transition of ruling thought of Communist Party of China and promoting the formation of thinking of rule of law. It also requests the party to proactively promote the reform of concrete ruling way, changing rule of man into rule of law and continuously innovate in the ways of rule of law. [18]

5) Transition of the social functions of Communist Party of China: Since the reform and opening up, the Communist Party of China raises and implements policies for strengthening country of socialist modernization with the farsighted view of times, having profoundly improved the leading system and ruling way of the party and optimized social functions of the party with modern characteristics.

Zhao Dapeng thinks we should base on the particularity of relationships between political party and country and society under Chinese context, then analyze the formation of the special functional structure of the Communist Party of China and conclude the special functions of the Communist Party of China as the function of leading nucleus, function of constructing and wielding state political power, function of social control and function of value shaping. The functional structure of the Communist Party of China is not changeless but has different characteristics under different historical conditions. According to the history after the founding of the People's Republic of China, the transition of the functional structure of the Communist Party of China has been divided into two periods of "omnipotence" and "administrative centralism", in order to analyze the main direction and objective for the transition of functional structure of the Communist Party of China at present. [19]

Jiang Weiping thinks social integration is one of the important functions of political parties as well as the fundamental duty that the ruling party must perform. As the only ruling party of China, the Communist Party of China must assume the responsibility, because it directly relates to the consolidation and expansion of the party's ruling foundation and is a significant test for the party's ruling ability and leadership standard. Therefore, we must give full play to interest integration, ideology integration and construction of harmonious society that are indispensable with the function of social integrity. [20]

\section{Analysis on the Dilemma for the Transition of Communist Party of China}

General Secretary Xi Jinping once proposed, "The system, road and today's unprecedented situation faced by our country are similar or close to even the same as that of the former Soviet Union". It indicates the transition of the Communist Party of China will not be smooth but encounter various dilemmas.

In respect of the organization structure of political party, $\mathrm{Su}$ Jian observes the Communist Party of China in the period of social transition is facing challenges from many aspects. First of all, the fading of struggle in the ideological sphere has raised doubts for the construction of the party's theoretical system. Secondly, with the development of economy and ceaseless improvement of social system, people's civic awareness constantly strengthens and the field that nongovernmental organization takes effect also expands continuously, reducing the range touched by the power of political party. Thirdly, the shortage of the party's institutional 
improvement has weakened the legitimacy and authority of ruling by the party. Communist Party of China must enhance the institutional improvement and strengthen the tracking and feedback strength of system performance and enforcement accountability. [21]

In regard to the ruling ability of political party, Gong Fangbin thinks, "Guevara Dilemma" is restricting the improvement of the party's ruling ability. It is difficult to break through the "Guevara Dilemma" in political and spiritual fields. Its self-sanctification leads to the behavior of departing from reality even neglecting objective existence. Under the situation of "the conditions of world, nation and party continue to change profoundly", it is still not down to earth. In terms of revolutionary ability, few political parties in the world can be comparable to the Communist Party of China that lets millions of followers devote themselves to pursuing the lofty ideal through theoretical education and spiritual infusion. It has contained the greatness of Communist Party of China, but the greatness in the revolutionary stage does not means the greatness also exists in the ruling stage. [22]

As for the spiritual pursuit of political party, Zhang Xiuqin thinks the spiritual pursuit of the Chinese communists has two dimensions: One point to the ultimate concern of human, the other point to the present realistic care in China. In practice, the public pay more attention to real benefit of ultimate concern, which has determined the spiritual pursuit of Chinese communists in the transition period. In face of the dilemma: the theoretical self-consciousness must be confident ideologically, meanwhile, the party should respond to the censure of non-Marxism even anti-Marxism; we must face modernity problems on individual existence. It is the crucial ways to solve problems of sluggish spirit through adhering to the spiritual pursuit of communists in historical logic and maintaining the transcendence of spiritual pursuit in the criticism of daily life. [23]

\section{Discussion on the Ways of Transition for Communist Party of China}

Facing the historic transition of Chinese society, the Communist Party of China must constantly adapt to the changed realistic environment via self-regulation, self-renewal and self-transcendence. Different opinions have formed in the academic circle on the path that should be selected in the transition of the Communist Party of China because of different views of research.

Zheng shucun thinks the ruling legitimacy construction of a political party is the basic guarantee of its long-term politics. We must realize the innovation and transition of ruling legitimacy to strengthen the construction of the party's ruling legitimacy. In the first place, build the "people-oriented" performance view and lay a performance foundation of ruling legitimacy. In the second place, build rational-legal authority and turn it into the dominance of ruling legitimacy. In the end, innovate in the ideology and lay the theoretical foundation for legal ruling. Ideology has been one of the legitimacy foundations of the political system, and the belief forms of ideology play a crucial role in proving and maintaining ruling legitimacy. [24]
Wang Liping thinks the fairness of existing system is questioned when phenomena like the widening of gap between the rich and poor, corruption of power and increasing prominence of social injustice universally exist in social life; when the broad masses of workers and peasants are increasingly marginalized, pauperized and lose the speaking right, the ruling foundation of ruling party will be shaken and the traditional authority of Communist Party of China will face challenges. The authority formed by the Communist Party of China is facing challenges, just as what American scholar Huntington say, the "performance legitimacy" appears problems. Therefore, the ruling party must change from the traditional authoritarian party to modern legal-rational party, in order to reshape the political authority of political party. [25]

Zhou Shuzhen observes the political system and code of conduct constructed by democratic principles, attitudes and habits are still the fundamental elements for democratic politics in China. The transition from the revolutionary political party to ruling party is "a change of natural evolution". The core for the transition of political party is to respond to the era and face the public with opener and more diversified ways. In order to realize the transition from revolutionary political party to democratic political party, it is necessary to emphasize the values of democracy on ideology; reject corruption and realize incorrupt government on the image; create organization framework system that better conforms to the characteristics of the times in the organization. [26]

Jia Lizheng addresses the theoretical innovation and path selection of transition should firmly grasp the principal line of strengthening the construction of the party's ruling ability, advancement and purity according to the requirements of building learning-based, service-based and innovation-based Marxism ruling party, and constantly improve the ability of the party in controlling the socialist market economy. [27]

\section{CONCLUSION}

The systematic organization of the research result regarding the transition of Communist Party of China has an important practical significance in further promoting the transition research of Communist Party of China. However, we need to further supplement and improve the research contents. Namely, we must pay attention to the research on the transition related to status and perspective from revolutionary political party to ruling party and the transition from the perspective of the relationships between political party and nation and society. Furthermore, we had better take full advantage of theories about politics and sociology and combine them together to discuss how the Communist Party of China should develop in the future. Secondly, the research methods must be innovated. We cannot simply mechanically apply theories of political parties in Europe because years of development history of Communist Party of China is totally different from the elution process of political parties in the continent of Europe. However, the typology of political parties in the West has provided thinking and methods for Communist Party of China in the perspective of "transition". We can form sounder theories related to the transition of political parties and conforming to the national conditions of China on the basis of referring to their thinking and methods. Communist Party of 
China will explore a road for the development of political party, conforming to the national conditions of China.

\section{REFERENCES}

[1] Michels: Iron Law of Oligarchy-Political Sociology in Modern Democratic System [M], Tianjin: Tianjin People's Publishing House, First edition in June 2002 米歇尔斯: 《葟头统治铁律——现代民主 制度中的政党社会学》[M], 天津: 天津人民出版社, 2002 年 6 月 第 1 版。

[2] America] Samuel P. Huntington, Change the Political Order in Society [M], Shanghai: Shanghai Joint Publishing Press, 1989 edition.[美]塞缪 尔.P. 亨廷顿.变动社会的政治秩序 $[\mathrm{M}]$, 上海: 上海三联书店出版 社, 1989 年版。

[3] [America] Macfarquhar, John King Fairbank, The History of the People's Republish of China in Cambridge [M], China Social Sciences Publishing house, 1994.[美]麦克法夸尔、费正清,剑桥中华人民共和 国史[M],中国社会科学出版社, 1994.

[4] LYU Zengkui. Transition of Holding Power -Discussion of Scholars at Abroad on the Construction of Communist Party of China [M], Central Compilation and Translation Press, 2011 吕增奎.执政的转型—海外 学者论中国共产党的建设[M],中央编译出版社, 2011

[5] Wang Guixiu, From Revolutionary Political Party to Ruling PartyPosition Transition in the Political Growth of Communist Party of China and Role Transition [J], Journal of the Party School of the Central Committee, 2008 王贵秀, 从革命党到执政党——中国共产党政治 成长中的地位转变与角色转换[J].中共中央党校学报,2008.

[6] Liu Nan. From Revolutionary Political Party to Ruling Party: Research on the Transition Issues of Communist Party of China [D], Jiangxi Normal University, 2010 柳楠.从革命党到执政党: 中国共产党转型 问题研究[D].江西师范大学, 2010

[7] Wang Lihua, Sun Qiongxian. Review and Summary on the Transition Process of Communist Party of China after the Establishment of State [J], The Journal of Yunnan Administration College, 2010 王丽华, 孙 琼仙. 建国后中国共产党转型历程的回顾与总结 [J].云南行政学院学 报, 2010 .

[8] Jiang Yiwei, Chen Yang. From Revolutionary Political Party to Ruling Party: Great Transition of Communist Party of China [J], Journal of Huzhou University, 2017 姜亦炜, 陈旸.从革命党到执政党: 中国共 产党的伟大转型[J].湖州师范学院学报, 2017.

[9] Xie Junyu. Transition from Revolutionary Political Party to Ruling Party-Reports of Congress of Party Representatives from the 8th National Congress of Communist Party of China to the 17th National Congress of Communist Party of China and Analysis on the Texts of All Previous Party Constitutions [J], Journal of Guizhou Institute of Socialism, 2011 谢君雨, 从革命党到执政党的转型——共八大到 十七大党代会报告及历届党章文本分析 [J].贵州社会主义学院学 报, 2011 .

[10] Tang Aijun. Transformation of Discourse of the Ideology of Communist Party of China [J], Journal of the Party School of the Central Committee, 2014 唐爱军, 中国共产党意识形态的话语转型 [J].中共中央党校学 报, 2014 .

[11] Huang Ruibo, LYU Yuanli. The Transition of the Ruling Style of Communist Party of China from Close to Open [J], Research Reports on the Politics of Contemporary China, 2012 黄锐波, 吕元礼.中国共产 党执政方式从封闭到开放的转型 [J]. 当代中国政治研究报告, 2012 .

[12] Li Guimin. From Policy to Law: Transition of Ruling Basis of Communist Party of China [J], Journal of Henan Normal University (Philosophy and Social Science Edition), 2005 李贵敏, 从政策到法律: 中国共产党执政依据的转型 [J].河南师范大学学报(哲学社会科学 版) , 2005 .

[13] Tao Lin. Globalization and the Transition of Ruling Legitimacy of Communist Party of China [J], Theoretical Investigation, 2010 陶林, 全球化与中国共产党执政合法性的转型 $[J]$.理论探讨, 2010

[14] Zhao Haitao. Intensification and Transition of the Basis of Ruling Legitimacy for Communist Party of China in the Period of Social Transition [D], Huaqiao University, 2005 赵海涛, 社会转型期中国共 产党执政合法性基础的强化与转型 $[\mathrm{D}]$. 华侨大学, 2005 .
[15] Liang Jiaming. Analysis on the Relationship between Social Transition in the Period of Reform and Opening up and Transformation of Cultura Construction of Communist Party of China [J], China-Today Forum, 2013 梁家铭, 改革开放时期的社会转型与中国共产党文化建设转 型关系探析[J].今日中国论坛，2013.

[16] Yang Fengcheng. 90 Years' of Cultural Views, Cultural Construction Policies and Cultural Transition of Communist Party of China [J], Journal of Renmin University of China, 2011 杨风城, 中国共产党 90 年的文化观、文化建设方针与文化转型 [J]. 中国人民大学学报, 2011

[17] Chen Chunsheng. Harmony Theory on the Transition of Conflict Theory-Objective Necessity of the Transition of Thinking Mode of Communist Party of China [J], Hebei Normal University Journal (Philosophy and Social Science Edition), 2011 陈春生.斗争论转向和 谐论一一中国共产党思维方式转型的客观必然性[J].河北师范大学 学报(哲学社会科学版), 2011.

[18] Zhang Bo. Legal Thinking and the Modern Transition of Ruling Thought of Communist Party of China [J], Theoretical Investigation, 2013 张波.法治思维与中国共产党执政思维的现代转型 [J].理论探 讨, 2013.

[19] Zhao Dapeng. Forms and Transition of the Functional Structure of Communist Party of China after the Establishment of State-Based on the Dimension of National and Social Relations [J], Theory and Reform, 2013 赵大朋.建国后中国共产党功能结构的形成与转型——基于国 家与社会关系的维度 $[J]$.理论与改革, 2013.

[20] Jiang Weiping. Research on the Social Conformity Ability of Communist Party of China in the Period of Social Transition [J], Party School of the Central Committee of CPC, 2010 姜卫平.社会转型期中 国共产党社会整合能力问题研究[J].中共中央党校, 2010 .

[21] Su Jian. Discussion on the Dilemma and Outlet of the Transition of Organizational Structure of Communist Party of China [J], Guide to Business, 2015 苏健.浅议中国共产党组织结构转型的困境及出路 [J]. 企业导报, 2015

[22] Gong Fangbin. "Guevara Dilemma" and the Transition of Communis Party of China [J], People's Tribune, 2013 公方涁.“格瓦拉困境”与中 国共产党转型 $[\mathrm{J}]$. 人民论坛, 2013

[23] Zhang Xiuqin. Dilemma of the Spiritual Pursuit of Chinese Communists in the Transition Period and Its Criticism, Journal of Hohai Univeristy (Philosophy and Social Science Edition) 2014 张秀勤. 转型时期中国共 产党人精神追求的困境及其批判, 河海大学学报 ( 哲学社会科学版) 2014

[24] Zheng Shuncun. Transition of Ruling Legitimacy of Communist Party of China and Its Path Selection [J], Literary History and Philosophy, 2005 郑曙村.中国共产党执政合法性的转型及其路径选择 [J].文史 哲, 2005.

[25] Wang Liping. Social Crisis and Party Transition-Based on the Perspective of Rule of Law [J], Journal of Party School of CPC Fujian Provincial Committee, 2017, (10) 王利平.社会危机与政党转型——基 于法治的视角[J].中共福建省委党校学报，2007,(10)

[26] Zhou Shuzhen. Promote the Development of Chinese Democratic Politics via the Transition of Political Party [J], Exploration and Contention, 2012, (10) 周淑真. 以政党转型促进中国民主政治发展 [J] 探索与争鸣, 2012,(10)

[27] Jia Lizheng. "Special Planning" Group of People's Tribune. Transition of Communist Party of China [J], People's Tribune, 2013 贾立政.人民 论坛“特别策划”组.中国共产党的转型[J].人民论坛，2013.

[28] He Zhe. Ruling Transition of Communist Party of China after the Reform and Opening up [M], Chinese Academy of Governance Press, 2016 何哲.改革开放后中国共产党的执政转型 $[\mathrm{M}]$, 国家行政学院出 版社, 2016 . 